\title{
Currency Substitution and Exchange Rate Volatility in Nigeria: An Autoregressive Distributed Lag Approach
}

Isaiah O. Ajibola, Sylvanus U. Udoette, Rabia A. Muhammad, and John O. Anigwe ${ }^{1}$

This study investigates the relationship between exchange rate volatility and currency substitution in Nigeria, using Autoregressive Distributed Lag (ARDL) model. After accounting for the presence of structural breaks, evidence from the findings shows that domestic interest rate and expected changes in exchange rate are important determinants of currency substitution. In addition, there is empirical support for a positive relationship between exchange rate volatility and currency substitution both in the short- and long-run. This implies that higher real exchange rate volatility is associated with an increased level of currency substitution. In view of these findings, the paper calls for sustained efforts by the monetary authority in containing exchange rate volatility and inflation as a way of curbing the spate of currency substitution in the country.

Keywords: Autoregressive distributed lag, currency substitution, exchange rate volatility, structural breaks

JEL Classification: C5, F3, F31

DOI: $10.33429 /$ Cjas.11220.1/8

\section{Introduction}

The traditional role of money as established in the literature shows three distinguished functions: as a medium of exchange; store of value; and unit of account. The existence of currency substitution (CS) is an indication of the failure of the national currency to effectively perform these functions due to some underlying macroeconomic conditions such as inflation, persistent depreciation or volatility in the value of the national currency (Agenor \& Khan, 1992; Clements \& Schwartz 1992; Tanzi \& Blejer, 1982; El-Khafif, 2002). Therefore, currency substitution can be described as a phenomenon where a domestic currency is being replaced by foreign currency due to the failure of the domestic currency to perform its roles effectively, as a means of payment and store of value.

\footnotetext{
${ }^{1}$ The authors are staff of Statistics Department, Central Bank of Nigeria

The views expressed in this paper are those of the authors and do not represent the views of the Central Bank of Nigeria.
} 
Currency Substitution and Exchange Rate Volatility in Nigeria: An Autoregressive Distributed Lag Approach. Ajibola et al.

Girton and Roper (1981), Bahmani-Oskooee and IIker (2003), Yeyati (2004), Boamah et al. (2012), and Laopodis (2011) have argued that the degree of currency substitution, otherwise known as "dollarization", can have significant negative implications for the domestic economy. Such negative effects include undermining the sovereignty of monetary policy, growing susceptibility to monetary tremors arising from the host nation, causing deterioration of the balance of payments account, exchange rate volatility, and contracting overall output (Bawa, Omotosho \& Doguwa, 2015). ${ }^{2}$ Currency substitution has negative economic implications for a country especially with regards to the conduct of monetary policy, as it undermines the transmission mechanism of monetary policy decisions. (See, Miles, 1978, Girton \& Roper, 1981; Ho, 2003; Boamah et al. 2012). Mizzen and Pentecost (1996) and Chang (2000) believe that currency substitution undermines the freedom of the exchange rate strategy and obfuscate monetary policy in a sphere where capital controls do not exist or are simply avoided. In other words, instead of permitting a country to regulate her monetary posture under an uncontrolled exchange rate, currency substitution creates undue inter-addiction amongst countries. Batten and Hafer (1984) also argued that currency substitution exposes an economy to external shocks and noted that domestic and foreign currencies should not be considered substitutes. This view is consistent with the monetary independence perspective. According to them, if domestic currency is substituted with the foreign currency, the domestic money demand would easily respond to adverse shocks emanating from both domestic and external sources.

In the context of Nigeria, some of the key works on currency substitution include Akinlo (2003), Yinusa and Akinlo (2008), Lionel and Ubi (2010), Adeniji (2013), Doguwa et al. (2014), Bawa et al. (2015), Huseyin et al. (2015) and Udoh and Udeaja (2019). A review of these studies showed that their findings are mixed. While Akinlo (2003) failed to establish the incidence of currency substitution in the country, the remaining studies provided empirical evidence in support of its existence and drivers. The divergent findings are attributable to issues surrounding difference in sample period, methodology and the measurement of the currency substitution indicator. This lack of definite conclusion necessitates the need for investigation in this area hence the justification for this study. It is believed that a proper understanding of the drivers of currency substitution in Nigeria is of crucial importance to

\footnotetext{
${ }^{2}$ See Cuddington (1983), Mizzen and Pentecost (1996), and Yinusa and Akinlo (2008), and

Bawa et al. (2015) for more explanation on currency substitution and exchange rate instability.
} 
monetary authority as well as conduct of monetary policy. Therefore, this study differs from the above studies and contributes to the literature in the following distinct ways: it employs the use of Autoregressive Distributed Lag (ARDL) model with structural breaks; it also controls for the effect of Exchange rate volatility; it has wide data coverage, using quarterly data for the period 1995-2018 that include recent economic episodes, especially the Nigeria's economic recession and exchange rate crisis of 2016.

The objective of this paper is to examine the degree of currency substitution in Nigeria and the effect of exchange rate volatility on currency substitution while accounting for the presence of structural breaks in the time series. To achieve this objective, the study applied the ARDL to quarterly data spanning 1995 - 2018. This methodology is useful in estimating models that may include variables of mixed orders, $\mathrm{I}(0)$ or $\mathrm{I}(1)$ and different lag-length.

The paper is organized into five sections. Following the introduction, Section 2 presents a review of relevant literature. Section 3 discusses the methodology while the results are presented in Section 4. The last section contains conclusion and policy recommendations.

\section{Literature Review}

This section provides a summary of theoretical and empirical literature on the degree of currency substitution and exchange rate volatility as well as some stylized facts on Currency Substitution in Nigeria.

\subsection{Theoretical Literature}

The concept of currency substitution has been hypothesized severally in literature with variant classifications and with no consensus theory on its definition ${ }^{3}$. Currency substitution can be described as a phenomenon where a domestic currency is being swapped for foreign currency due to the failure of the domestic currency to perform its roles effectively, as a means of payment and store of value. It is a measure of the degree that currencies are substitutes in the portfolio of wealth holders, Girton and Roper (1976). Traditionally, each country has its own currency use as means of exchange therefore, when there are multiple currencies used for the same purpose, a stronger foreign currency competing with or substituting the domestic currency, then currency substitution is said to occur. Currency substitution is often caused by persistent macroeconomic instability in a country. During high inflation periods,

\footnotetext{
${ }^{3}$ See Giton and Roper (1976), Ho (2003), Calvo and Vegh (1992), and De Nicolo et al. (2005).
} 
Currency Substitution and Exchange Rate Volatility in Nigeria: An Autoregressive Distributed Lag Approach. Ajibola et al.

economic agents hold diversified portfolios of foreign currencies as a result of depreciation of the local currency with the intention of reaping profit in the future. The presence of ratchet effect makes economic agents to continue using foreign money in the financial system even after the high inflation periods and the expected differential in return leads to instability in the domestic money demand function making monetary policy management ineffective, Calvo and Vegh (1992). Residents tend to adjust their portfolio holdings to more stable foreign currencies in anticipation of further devaluation of the domestic currency to safeguard against high risk of the exchange rate, which consequently leads to decline in domestic currency demand function (Yeyati, 2004; Yinusa \& Akinlo, 2008). The eroded confidence in the domestic currency among other factors, culminate into currency substitution as well as currency crisis and exchange rate instability. The effects of dollarization culminated from persistent macroeconomic instability is evidenced in developing countries like Zimbabwe, Panama and Ecuador. These countries experienced severe hyperinflation with no choice but to dollarize.

Currency substitution also known as dollarization is categorized as "partial" or "full". According to Andrew et al. (2000), full dollarization means taking the next step, from informal, limited dollarization to full, official use of a foreign currency in all transactions, as a medium of exchange, unit of account and as a store of value within an economy. Whereas partial dollarization connotes a limited, unofficial form of dollarization mostly common in high inflation countries, which to a greater or lesser degree, is indicated by residents' preference to hold more of foreign currency and foreign currency-denominated deposits at the domestic banks, only as a store of value and portfolio diversification against macroeconomic instability and risk of exchange rate depreciation, and less of the riskier and unstable domestic currency. However, apart from the negative implications of currency substitution or dollarization, there are some benefits that come with it. According to Schuler (2002), ${ }^{4}$ dollarization causes the following:

1. An officially dollarized country enjoys the reduction of inflation rate from double digit to a single digit inflation of the foreign or issuing country.

2. Reduction of the transaction cost of currency exchange. That is, the cost of converting domestic currency to foreign currency is low.

\footnotetext{
${ }^{4}$ The benefits of currency substitution or dollarization are well discussed in Schuler (2002)
} 
3. High level of domestic investment and future economic growth as a result of reduced and stable interest rates for local borrowers.

4. Assists financial institutions to develop, improve efficiency and quality of services. It also fosters financial integration with the issuing country as well as builds credibility with the government by adopting issuing country's policies.

5. Fosters high levels of economic openness and transparency on the part of the government and eliminates balance of payments crisis.

Several approaches are found in theoretical literature for modelling the process of currency substitution with a large portion adopting the portfolio balance model approach of the money demand function. (see, Thomas, 1985; Yinusa \& Akinlo, 2008; Doguwa, 2014). The cashin-advance model based on the use of money as a medium of exchange (Clower, 1967; Lucal $\&$ Stoky, 1987) and the transactional model which hinges on the store of value function of money (Baumol, 1952; Tobin, 1956) formalized the macroeconomic foundation of the money demand function. ${ }^{5}$ The main theoretical basis of these models lies in the belief that demand for foreign currency largely depends on the interest rate differentials and the associated exchange rate risks. Baumol (1952) in his portfolio balance model, shows that transaction demand for money is interest inelastic whereas Keynes expresses that it is mostly interest inelastic and income elastic. The portfolio balance model is based on an ideal holding of money for transaction purposes. Economic agents hold money in the form of cash and assets to bridge the differences between income and expenditure, or for its return as an asset in a portfolio (Thomas, 1985). In both cases, the demand for money may rest on a scale of variables, such as wealth, real income or on the returns to money and other assets, which is the opportunity cost variable or the substitution effect. This substitution effect is captured by the interest rate on the assets invested in by the economic agents. The Maintenance of minimum transaction balances allows firms to maximize returns from assets. According to De Nicola et al. (2003), the portfolio balance model follows the assumption that money demand functions positively depends on scale variables such as wealth or income and negatively on the return of each substitute asset. However, other studies (Calvo \& Vegh, 1992; Cuddington, 1989)

\footnotetext{
${ }^{5}$ Clower (1967), Lucal and Stoky (1987), Baumol (1952), and Tobin (1956) for more discussions
} on the evolution and macro-foundation of the money demand function. 
show no such distinguishing features between money and assets.

Cuddington (1983) proposed portfolio balance approach that emphasizes the simultaneous allocation of wealth between various types of money and other assets, both domestic and foreign. Under the assumption of perfect capital mobility, the holding of both domestic and foreign money as well as bonds are allowed by individuals. The expected return on all assets and real income determines the portfolio share of all assets.

This study adopts a variant of the multi-perspective unrestricted portfolio balance approach to demand for money originally founded by Tobin (1969), the Cuddington's portfolio balance model which uses the money demand function for the estimation. This model proposed by Cuddington (1983) is unrestricted and allows multiple and simultaneous holding of both currency and assets by economic agents and inclusion of structural break. Domestic agents can diversify their portfolio holding and have a mixture of four assets, consisting of both domestic and foreign assets: money, domestic bonds, foreign currency, and foreign bonds. Thus, the model contains distinct money demand function for both domestic and foreign assets and to measure the demands for real balances of these assets, the model adopts following functions:

$$
\begin{aligned}
& M^{d}=m\left(i, i^{*}, e^{*}, x, y\right) \\
& B^{d}=b\left(i, i^{*}, e^{*}, x, y\right) \\
& M^{f}=M^{f}\left(i, i^{*}, e^{*}, x, y\right) \\
& B^{f}=b^{f}\left(i, i^{*}, e^{*}, x, y\right)
\end{aligned}
$$

where, $\mathrm{M}^{d}$ stands for demand for domestic money, $\mathrm{B}^{d}$ is demand for domestic bonds, $\mathrm{M}^{f}$ and $\mathrm{B}^{f}$ are demand for foreign money and bonds respectively, $i$ and $i^{*}$ denote returns on holding domestic and foreign bonds in the portfolio of domestic agents respectively, $e^{*}$ is the expected change in the domestic exchange rate, $\mathrm{x}$ is the expected rate of domestic currency depreciation, and y represents domestic income. The CS model specification used in this work, is in line with the above two money-demand functions (see equation 5).

\subsection{Empirical Literature}

There are numerous studies on currency substitution with different methodologies that cuts across the world; developed, developing and underdeveloped countries. Those studies specific on Nigeria include the works of Akinlo (2003), Yinusa and Akinlo (2008), Lionel and 
Ubi (2010), Doguwa (2014) and Huseyin, Abdurrahman and Gylych (2015). Akinlo (2003) used the cointegration approach to investigate the impact of Nigeria's Naira depreciation on currency substitution in the country. Based on quarterly data, the paper estimated a money demand function that includes exchange rate, income and interest rate. The results failed to find evidence to support that view that depreciation of Nigeria's Naira decreased domestic money holdings.

Huseyin et al. (2015) using the same technique, investigated the relationship between currency depreciation and currency substitution in Nigeria during the period 1980 to 2013. Based on their cointegration test that included variables such as money supply, real income, nominal interest rate and nominal effective exchange rate, it was found that Naira depreciation causes currency substitution in the country.

Yinusa and Akinlo (2008) studied the existence of foreign exchange rates volatility and the extent of currency substitution in Nigeria using a multi-perspective unrestricted portfolio balance model and Vector Error Correction (VEC) technique on exchange rate volatility. The study utilized quarterly data from 1986:1 to 2005:2. The findings from this paper showed a significant existence of currency substitution which was basically driven by exchange rate instability, impact of external policy on the local economy, and an elongated era of high price increases. Their results also showed that the under-developed state of the country's financial market hindered well-organized portfolio diversification and contributed to the incidence of currency substitution. They concluded that currency substitution does not instantly react to changes in monetary policy and argued that while it takes quite some time before people start holding foreign currency in place of the local, the reversal is quite hard to achieve.

Lionel and Ubi (2010) examined the vulnerability of the Nigerian economy to currency substitution using annual data spanning 1970 - 2008. Results from their estimated vector error correction found empirical support for the presence of currency substitution, driven largely by factors such as persistent inflation, depreciation of the naira occasioned by exchange rate instability, and monetary policy inconsistency. They explained that domestic agents exchange local currency for the foreign once they perceive that there is a loss of purchasing power from holding the home currency due to inflation risk, exchange rate risk, or political instability. It was then suggested that measures should be taken by the monetary authorities to rein in inflation and exchange rate volatility. 
Currency Substitution and Exchange Rate Volatility in Nigeria: An Autoregressive Distributed Lag Approach.

Ajibola et al.

Other currency substitution studies on Nigeria employed autoregressive distributed lag (ARDL) Model. These include the work of Adeneji (2013), Doguwa (2014) and Bawa et al. (2015). Adeniji (2013) investigated the relationship amongst legal tender replacement and some macroeconomic indicators such as exchange proportion, price increases and interest proportion in Nigeria by means of a projected Autoregressive Distributed Lag (ARDL) model. Based on data for the period 1970 - 2012, the study found a steady and long-run correlation amongst currency substitution and the macroeconomic variables considered. Furthermore, he showed that exchange rate and inflation are positively related to currency substitution both in the short- and long-run.

Doguwa (2014) estimated an autoregressive distributed lag model to identify the drivers of currency substitution in Nigeria between the period 2007 and 2011. He found that short-term foreign interest rates, devaluation expectations, exchange rate risk and political uncertainties are significant determinants of currency substitution. He found empirical support for the presence of currency substitution in the country which can expose the economy to external shock and generating macroeconomic instabilities.

Bawa et al. (2015) examined the persistence of currency substitution in Nigeria by including a ratchet variable in their projected Autoregressive Distributed Lag (ARDL) model. Beyond establishing the presence of currency substitution in the country during the period 1990 - 2013, they also found that the significant determinants of currency substitution were exchange rate hazards, predictable exchange rate devaluation, exchange rate spread, price increase potentials and the ratchet variables. According to them, the presence of currency substitution in the country may hamper the steadiness of the money demand role as well as the efficacy of monetary policy.

The most recent study on currency substitution in Nigeria by Udoh and Udeaja (2019) investigated the relationship between financial dollarization and nominal exchange rate volatility in Nigeria applying Threshold Autoregressive Conditional Heteroscedasticity (TARCH) model covering the period December 2009 to September 2018 using monthly data. The findings showed that the degree of financial dollarization has a great impact on exchange rate volatility in the country. It also revealed that there is a high degree of persistence and ratchet effect exhibited by the exchange rate volatility. 
Further reviewed empirical studies on some developed and developing countries include that of Hisao and Masao (2014) studied the impact of currency substitution on nominal exchange rate volatility in seven emerging countries, namely: Indonesia, Philippines, the Czech Republic, Hungary, Poland, Argentina, and Peru. They found that the degree of currency substitution has significant positive effects on the conditional variance of the nominal exchange rate in the countries. This means that a rise in the degree of currency substitution increases exchange rate volatility in most of the selected countries. They proposed that since the emerging countries are characterized by shallow currency markets and short histories of stable inflation, stability is achieved by responding to exchange rate movements proactively. This negates the argument common amongst central banks in advanced countries that monetary policy should only respond to exchange rate movements if it threatens the inflation objective.

To test the importance of currency substitution in Korea, Arize (1991) estimated a domestic demand for money function and used the same to determine if currency substitution significantly influences the holdings of domestic real money balances. His findings showed that currency substitution has a negative effect on the demand for money.

Laopodis (2011) noted that a high degree of currency substitution undermines monetary independence in the domestic economy and thus matters for the decision of a country to join a monetary union. To understand this phenomenon, he used an estimated error correction model to investigate the effects of the presence of currency substitution on the effectiveness of European Monetary Union in both the short- and long-run. Taking the case of the anticipated participation of three emerging European countries of Greece, Portugal and Spain in the monetary union, the work revealed a weak evidence of currency substitution in the countries.

Boamah et al. (2012) studied legal tender substitution in the Caribbean Republics of Guyana, Jamaica, Trinida and Tobago and Barbados using quarterly data from 1996 to 2009. The study investigated the extent to which foreign currency deposits affect the total transactions balance of the money stock as a result of exchange rate changes. Based on their analysis from an estimated ARDL model, the paper found empirical support for currency substitution driven by exchange rate shocks in the four countries.

In view of the findings of the literature reviewed, undoubtedly currency substitution is com- 
Currency Substitution and Exchange Rate Volatility in Nigeria: An Autoregressive Distributed Lag Approach. Ajibola et al.

monly driven by inflation, depreciation, exchange rate volatility and to some extent, foreign interest rates in both developed and developing countries. In the case of Nigeria, presence of ratchet effect is also reported in two instances. The ratchet variable with a long run significant influence indicates the persistence of currency substitution in Nigeria with all attendant economic and monetary policy implications. However, this study seeks to reinvestigate the degree of currency substitution in Nigeria and the effect of exchange rate volatility on currency substitution by means of ARDL model.

\subsection{Stylized Facts}

In empirical work of this nature, there are several widely used quantitative measures of currency substitution that are adopted. One of such measures include the "narrow" measure, which we will denote CS1 and the "broad" measure, denoted as CS2 adopted by Doguwa (2014) and Bawa et al. (2015) in their respective studies on currency substitution in Nigeria. The narrow definition CS1, which is simply the ratio of foreign currency denominated deposit to demand deposit in the banking system, visualizes currency substitution only in the realm of the foreign currency displacing the national currency as a medium of exchange. However, the broad measure CS2, being a ratio of foreign currency denominated deposit to the sum of demand deposit, term deposit and savings deposits views currency substitution in the realm of the foreign currency displacing the national currency as a store of value (inflation consideration).

Evidence from Figure 1 shows similar movements in the quarterly values of the two indices of currency substitution over the study period (Q1 1995 - Q4 2018). During the period, CS1 and CS2 rose steadily over time. The trend in the two measures indicates a steady increase in the degree of currency substitution in Nigeria, reaching its peak in the first quarter of 2014. However, CS2 remained largely within the International Monetary Funds (IMF)' threshold of 30 per cent for most of the period under review (IMF, 1999).

The global financial crisis of 2007/08 mounted substantial pressure on the local currency which resulted in the depreciation of the Naira. Consequently, the currency substitution indices began to rise, reaching the peak of 98.2 per cent and 43.1 per cent for CS1 and CS2, respectively in Q4 2014. However, the CBN was preemptive in protecting the value of the Naira during the period, in line with its core mandate of safeguarding the international value of the legal tender currency. Providentially, the economy was resilient at the beginning of the 
crisis, with her gross external reserves totaling US $\$ 54.2$ billion in January 2008 and attaining the highest level of US\$62.08 billion in September 2008. However, as economic pressures continued to mount, the value of the local currency (exchange rate) and the international price of crude oil continued to plunge. Nevertheless, the CBN sustained her interventions in the foreign exchange market in order to safeguard the worth of the Naira. These interventions had a significant impact on the country's external reserves, which dropped progressively as the crisis deteriorated.

All through this period under review, various exchange rates regimes have existed. For the avoidance of doubt, this refers to the method or system adopted by the monetary authority to determine the rate of exchange of a unit of domestic currency in exchange for units of other foreign currencies. In the case of Nigeria, the CBN has over the years worked assiduously to preserve the value of the domestic currency from the era of the Nigerian Pound to the current currency, the Naira. Several exchange rate management systems have been deployed at various times in the country's history such as fixed, floating and pegged float to determine the appropriate rate of exchange for the naira vis-à-vis the major trading currencies since the establishment of the Bank in 1958.

The development of the foreign exchange market in Nigeria up to what currently exists have been as a result of various issues relating to international trade, changes in the economy and structural shifts in production. At different stages laws have been enacted such as the Exchange Control Act of 1962. At the early stages foreign exchange was earned by the private sector. The major source of the bulk of foreign exchange receipts were from agricultural exports. The Nigerian pound was tied to the British pound sterling at par, which constituted a major setback to the development of an active foreign exchange market in the economy.

In a bit to address the various foreign exchange misalignment in the country, the monetary authority has introduced various exchange rates management programmes. In 1982, due to the foreign exchange crisis an inclusive exchange control system was introduced. The parallel market for foreign exchange came on board to address the shortfall in the supply of foreign exchange. As days passed different schemes were introduced. This includes the Second-tier Foreign Exchange Market (SFEM) in 1986, the introduction of Foreign Exchange Market Bureaux de Change in 1989 to deal with the privately sourced foreign exchange, etc. 
Currency Substitution and Exchange Rate Volatility in Nigeria: An Autoregressive Distributed Lag Approach.

Ajibola et al.

These birthed more reforms as they could not solve the foreign exchange problems, rather volatility in the rates was experienced. Such reforms include the formal pegging of the naira exchange rate, the centralization of foreign exchange in the CBN, the restriction of Bureaux de Change to buy foreign exchange as agents of the CBN, the reaffirmation of the illegality of the parallel market and the discontinuation of open accounts and bills for collection as means of payments sectors.

Other reforms include the liberalization of the foreign exchange market in 1995 where the Autonomous Foreign Exchange Market (AFEM) was created and the introduction of an Interbank Foreign Exchange Market (IFEM) in 1999. At different points, the CBN has adopted the Retail Dutch Auction System (RDAS) and the Wholesale Dutch Auction System (WDAS) in a managed float regime to bridge the gaps that existed in foreign exchange market. However, the CBN closed the RDAS system in February 2015.

The monetary authority in April 2017 introduced the Investors and Exporters Windows in the currently managed flexible floating regime to deepen the foreign exchange market and accommodate all foreign exchange obligations. The whole essence of the current regime is to increase liquidity in the market and assure prompt business settlement.

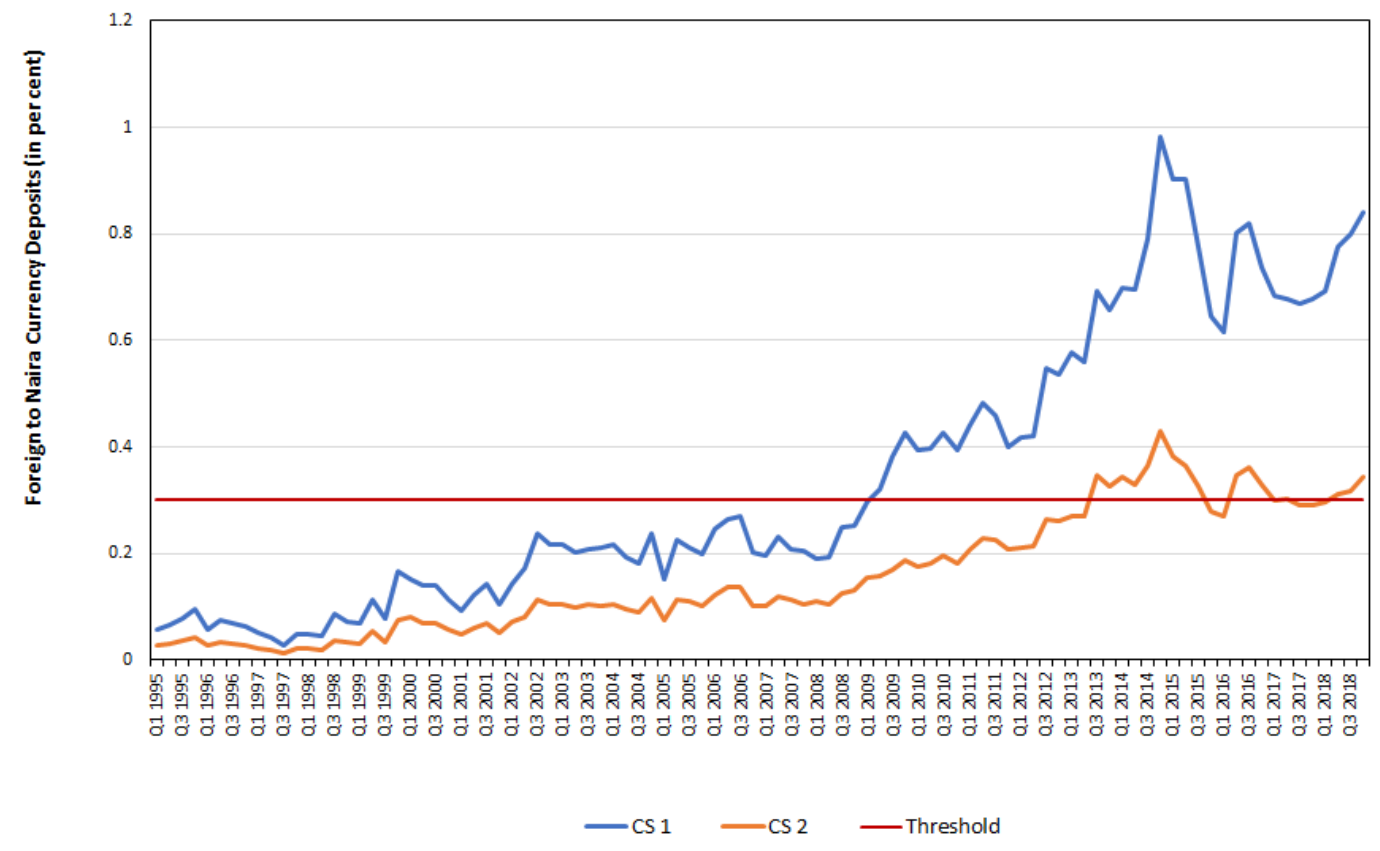

Figure 1: Currency Substitution in Nigeria 1995Q1 to 2018Q4 
The peak in currency substitution recorded in 2014 may not be unconnected to the instabilities created by the decline in oil price, which led to a substantial depletion of the external reserves and a depreciation of the exchange rate. These triggered increases in currency substitution particularly the US Dollars and other major convertible currencies. In response to the exchange rate pressure of 2014, the Central Bank of Nigeria on April 17, 2015, issued a circular that stopped the practice of accessing the foreign exchange market for settling domestic transactions. The circular also contained the mandate to suspend the use of foreign currency in customers' domiciliary accounts for transactions in the form of fees, charges, licenses, etc., that originated and expected to be concluded in Nigeria. The circular also specifically overruled Memorandum 16 of the CBN Manual which had permitted banks to use independent sources of foreign exchange in domiciliary accounts to settle invoices relating to the supply of goods and services. A combination of these efforts aimed at stabilizing the foreign exchange market may have resulted in the decline in the degree of currency substitution indices in 2015.

\section{Data and Methodology}

\subsection{The Model}

To ensure robustness in our analyses, two widely used indices of currency substitution in empirical studies are adopted. The first measure, denoted as CS1, defines currency substitution (CS) as per proportion of external currency deposits (ECD) to local currency demand deposits (DD) while the second measure, denoted as CS2, considers the proportion of external currency deposit (ECD) to the sum of Naira demand deposit (DD), term deposit (TD), and savings deposits (SD) in the finance structure. These definitions are in line with Doguwa et al. (2014) and Bawa et al. (2015) who described $\mathrm{CS}_{t}$ as a narrow definition of currency substitution and $\mathrm{CS}_{t}$ as a broad measure of currency substitution. Based on these two definitions, and following the standard money demand function as in Yinusa and Akinlo (2008), we specify the currency substitution index models for Nigeria as:

$$
\begin{aligned}
& C S_{t}=\beta_{0}+\beta_{1} C P I_{t}+\beta_{2} R G D P_{t}+\beta_{3} P L R_{N G N t}+\beta_{4} P L R_{U S t}+\beta_{5} R E R E X P_{t} \\
& +\beta_{6} N E R V_{t}+\beta_{7} R E R V_{t}+\lambda D 1_{t}+\omega D 2_{t}+\varepsilon_{t}
\end{aligned}
$$

Equation 5 is estimated consecutively across $C S 1_{t}$ and $C S 2_{t}$. 
Currency Substitution and Exchange Rate Volatility in Nigeria:

where:

$$
C S 1_{t}=\frac{E C D_{t}}{D D_{t}} \quad \text { and } \quad C S 2_{t}=\frac{E C D_{t}}{D D_{t}+S D_{t}+T D_{t}}
$$

The notation $R G D P_{t}$ represents real gross domestic product, $C P I_{t}$ is consumer price index, $R E R E X P_{t}$ represent exchange rate expectation $\left(R E R E X P_{t}=R E R_{t+1}-\right.$ lead RER), $N E R V_{t}$ denote nominal exchange rate volatility, $R E R V_{t}$ denote real exchange rate volatility while $P L R_{N G N_{t}}$ and $P L R_{U S t}$ are measures of return on money represented by interest rate in Nigeria and the United States, respectively at time t. $\varepsilon_{t}$ is the random error term. To assess the role of exchange rate volatility as a determinant of currency substitution, equation 5 is estimated with and without the two exchange rate volatility variables. The data used for the estimation are based on quarterly observations spanning 1985 to 2018 obtained from the CBN statistics database and the IMF website.

The variables in equation 5 are included in the model in their logarithmic form, except for interest rates. The exchange rate volatility variable, $E R V_{t}$, is derived using a standard GARCH $(1,1)$ in the spirit of Yinusa and Akinlo (2008). The GARCH $(1,1)$ is of the form of:

$$
\begin{aligned}
& \text { LNERV }_{t}=c+\operatorname{LNERV}_{t-1}+\varepsilon_{t} \\
& \sigma_{t}^{2}=\alpha_{0}+\alpha_{1} \varepsilon_{t-1}^{2}+\alpha_{2} \sigma_{t-1}^{2}
\end{aligned}
$$

where equation 6 is a mean equation for the nominal exchange rate and equation 7 expresses the fitted variance for the nominal exchange rate as a weighted average of a long-term average value $\left(\alpha_{0}\right)$, information about volatility in the previous period $\left(\varepsilon_{t-1}^{2}\right)$ and the estimated variance from the previous period $\left(\sigma_{t-1}^{2}\right)$. The real exchange rate volatility variable, $R E R V_{t}$, is derived in a similar fashion. To take care of the structural breaks, the breakpoints were determined exogenously. The first break point considers the transition from military to democratic rule in 1999 (i.e. D1= 1999Q2) while the second accommodates the rebasing of the country's economy to a base of 2010 (i.e. D2 $=2010$ Q3). We are of the view that the uncertainties around the transition to democratic governance in 1999 caused market jitters and a consequent capital reversal in the capital market.

Equation 5 is estimated using bounds testing approach to Cointegration otherwise referred to as Autoregressive Distributed Lag (ARDL) model proposed by Pesaran and Shin (1999) and Pesaran, Shin and Smith (2001). The implementation of ARDL consists of two stages. The 
first stage establishes the existence of cointegration amongst the variables through bounds testing, while the second stage involves estimating the long-run and short-run models. The choice of this methodology is predicated on its usefulness in estimating models that may include variables that are $\mathrm{I}(0)$, I(1), or fractionally integrated. In addition, it involves a single equation format which makes it easy to implement and interpret and can also accommodate different variables with varied lag-length in a model.

Pesaran et al. (2001) tabulated two critical bounds (i.e. upper and lower bounds) for the asymptotic distribution of the test statistics. The lower bound is built on the hypothesis that underlying indicators are exclusively $\mathrm{I}(0)$ and the upper bound variables wholly adopt $\mathrm{I}(1)$. If the calculated test statistics drops beneath the lower bound, this implies that the variables are $\mathrm{I}(0)$ and therefore there is no cointegration. On the other hand, if the statistics exceeds the upper bound, the variables are I(1) and this confirms cointegration. However, if the statistics is in between the two bounds, then the result is inconclusive. Akaike Information Criterion (AIC) is used to determine the optimal lag length for the variables on the right-hand side. The representation of the ARDL model for the two variants of the currency substitution index are specified as follows:

$$
\begin{aligned}
\Delta L C S_{t}= & \beta_{0}+\sum_{i=1}^{p} \beta_{1 i} \Delta L C S 1_{t-i}+\sum_{i=0}^{q} \beta_{2 i} \Delta L C P I_{t-i}+\sum_{i=0}^{r} \beta_{3 i} \Delta L R G D P_{t-i} \\
& +\sum_{i=0}^{s} \beta_{4 i} \Delta P L R_{N G N t-i}+\sum_{i=0}^{u} \beta_{5 i} \Delta P L R_{U S t-i}+\sum_{i=0}^{v} \beta_{6 i} \Delta L R E R E X P_{t-i} \\
& +\sum_{i=0}^{w} \beta_{7 i} \Delta L N E R V_{t-i}+\sum_{i=0}^{x} \beta_{8 i} \Delta L R E R V_{t-i}+\delta_{1} L C S 1_{t-1}+\delta_{2} L C P I_{t-1} \\
& +\delta_{3} L R G D P_{t-1}+\delta_{4} \Delta P L R_{N G N t-1}+\delta_{5} \Delta P L R_{U S t-1}+\delta_{6} \Delta L R E R E X P_{t-1} \\
& +\delta_{7} L N E R V_{t-1}+\delta_{8} L R E R V_{t-1}+\lambda D 1_{t}+\omega D 2_{t}+e_{t}
\end{aligned}
$$

where $\beta_{s}$ and $\delta_{s}(s=1,2, \ldots, 8)$ represent the short-run and the long-run framework of the model respectively, $\Delta$ is a differenced operative and $p, q, r, s, u, v, w$ are the respective lag lengths assigned to the variables in the model.

As proposed by Pesaran et al. (2001), we examine for cointegration amongst variables using standard Fisher test by testing a null hypothesis of no co-integration amongst the variables alongside the occurrence of cointegration as follows:

$$
H_{0}: \delta_{1}=\delta_{2}=\delta_{3}=\delta_{4}=\delta_{5}=\delta_{6}=\delta_{7}=\delta_{8}=0 \quad v s \quad H_{1}: \delta_{i} \neq 0 \forall i=1,2, \ldots, 8 .
$$


When the existence of cointegration is recognized, a suitable autoregressive distributed lag error correction representation of the model will be as follows:

$$
\begin{aligned}
\Delta L C S_{t}= & \beta_{0}+\sum_{i=1}^{p} \beta_{1 i} \Delta L C S 1_{t-i}+\sum_{i=0}^{q} \beta_{2 i} \Delta L C P I_{t-i}+\sum_{i=0}^{r} \beta_{3 i} \Delta L R G D P_{t-i} \\
& +\sum_{i=0}^{s} \beta_{4 i} \Delta P L R_{N G N t-i}+\sum_{i=0}^{u} \beta_{5 i} \Delta \operatorname{lnPLR} R_{U S t-i}+\sum_{i=0}^{v} \beta_{6 i} \Delta L R E R E X P_{t-i} \\
& +\sum_{i=0}^{w} \beta_{7 i} \Delta L N E R V_{t-i}+\sum_{i=0}^{x} \beta_{8 i} \Delta L R E R V_{t-i}+\lambda e c_{t-1}+\lambda D 1_{t} \\
& +\omega D 2_{t}+e_{t}
\end{aligned}
$$

The $\lambda$ represents the adjustment parameter that signifies the speed of adjustment at which stability is re-established given a shock.

It should be noted that, equations 8 and 9 are estimated consecutively across $\Delta L C S 1_{t}$ and $\Delta L C S 2_{t}$.

\section{Results and Discussion}

In this section, we present the results of the unit root test, the bounds test for cointegration, the ARDL model results as well as the post estimation diagnostics relevant in evaluating the validity of the estimated model.

\subsection{Descriptive Statistics}

The summary statistics of the variables included in the model is presented in Table 1. Evidence from the table shows that the average values for CS1 and CS2 are of 0.34 and 0.16, respectively. Also, the computed standard deviations also revealed that CS1 is more volatile than CS2 with 0.26 and 0.11 , respectively. In addition, the skewness and kurtosis show the non-normality of the distribution and this is further confirmed by the Jacque-Bera statistics. 
Table 1: Summary of Variables Statistics

\begin{tabular}{llllllllll} 
Statistic & CS1 & CS2 & CPI & RGDP & REREXI & PLR_NG & PLR_U & RERV & NERV \\
\hline Mean & 0.34 & 0.16 & 94.97 & 11394.99 & 151.94 & 18.48 & 5.54 & 330.78 & 142.15 \\
Median & 0.23 & 0.11 & 75.12 & 10797.54 & 142.69 & 17.72 & 4.75 & 344.87 & 149.70 \\
Maximum & 0.98 & 0.43 & 268.41 & 18563.50 & 265.74 & 26.25 & 9.50 & 347.28 & 150.10 \\
Minimum & 0.03 & 0.01 & 18.81 & 5699.55 & 56.10 & 14.88 & 3.25 & 183.72 & 0.01 \\
Std. Dev. & 0.26 & 0.11 & 67.52 & 3984.06 & 56.81 & 2.41 & 2.24 & 32.46 & 21.71 \\
Skewness & 0.75 & 0.60 & 0.88 & 0.27 & 0.22 & 1.22 & 0.38 & -2.69 & -4.28 \\
Kurtosis & 2.31 & 2.11 & 2.79 & 1.71 & 2.27 & 4.27 & 1.45 & 9.93 & 23.95 \\
Jarque-Bera & 10.76 & 8.82 & 12.34 & 7.64 & 2.84 & 29.57 & 11.69 & 301.49 & 2006.29 \\
Probability & 0.0046 & 0.0122 & 0.0021 & 0.0219 & 0.2418 & 0.0000 & 0.0029 & 0.0000 & 0.0000 \\
Observations & 94 & 94 & 94 & 94 & 94 & 94 & 94 & 94 & 94 \\
\hline
\end{tabular}

\subsection{Unit Root Test}

All the variables included in the model were tested for the presence of unit root using both the Augmented Dickey-Fuller (ADF) and the Phillips-Perron (PP) tests. The choice of ADF technique emanates from the fact of its recommendation by Pesaran et al. (2001) that developed the ARDL model. However, Phillips-Perron is added for robustness check. The variables included in the model are a mix of both $\mathrm{I}(0)$ and $\mathrm{I}(1)$, justifying the use of ARDL model.

Table 2 : Unit Root Test

\begin{tabular}{llllll}
\hline & \multicolumn{2}{c}{ Level } & \multicolumn{2}{c}{ First Difference } & \multicolumn{2}{l}{ Decision } \\
Variable & ADF & PP & ADF & PP & $\mathrm{I}(\mathrm{d})$ \\
\hline LCS1 & $-1.9966 \mathrm{a}^{* *}$ & $-4.2514 \mathrm{c}^{*}$ & - & - & $\mathrm{I}(0)$ \\
LCS2 & $-2.0462 \mathrm{a}^{* *}$ & $-4.0555 \mathrm{c}^{* *}$ & - & - & $\mathrm{I}(0)$ \\
LCPI & - & - & $-5.1567 \mathrm{a}^{*}$ & $-5.4813^{*}$ & $\mathrm{I}(1)$ \\
LRGDP & - & $-8.1132 \mathrm{c}^{*}$ & $-3.1565 \mathrm{~b}^{* *}$ & - & $\mathrm{I}(1)$ \\
PLR_NGN & - & - & $-7.9258 \mathrm{a}^{*}$ & $-8.0101 \mathrm{a}^{*}$ & $\mathrm{I}(1)$ \\
PLR_USA & - & - & $-3.9968 \mathrm{a}^{*}$ & $-4.0889 \mathrm{a}^{*}$ & $\mathrm{I}(1)$ \\
LREREXP & - & - & $-9.0554 \mathrm{a}^{*}$ & $-9.0547 \mathrm{a}^{*}$ & $\mathrm{I}(1)$ \\
LRERV & $-4.5102 \mathrm{~b}^{*}$ & $-4.5102 \mathrm{~b}^{*}$ & - & - & $\mathrm{I}(0)$ \\
LNERV & $-8.9059 \mathrm{~b}^{*}$ & $-8.9059 \mathrm{~b}^{*}$ & - & - & $\mathrm{I}(0)$
\end{tabular}

NB: a indicates regression without constant and trend; $b$ indicates regression with only constant; and c indicates regression with constant and trend. $*$ and $* *$ indicate significance@1\% and 5\% respectively

\subsection{Bounds Test for Cointegration}

As earlier explained, we estimated three variants of the model for CS1 specified in equation 1. In the upper panel of Table 3, the results of the cointegration tests for the three model variants are presented. Model 1 accommodates all the variables in equation 1 with the exception of $N E R V_{t}$. Model 1 accommodates all the variables in equation 1 with the exception of $R E R V_{t}$ while Model 3 accommodates all the variables in equation 1. Similar variants of the three 
Currency Substitution and Exchange Rate Volatility in Nigeria: An Autoregressive Distributed Lag Approach. Ajibola et al.

models are also considered for the broad definition of currency substitution denoted as CS2. These are Models 4 - 6 and the respective bounds test results are presented in the lower panel of Table 3.

Evidence from the bounds test showed that the variables included in the 3 variants of the models for LCS1 and LCS2 are cointegrated with the computed F statistics higher than the upper bound critical value of 3.99 at $1 \%$ level of significance. Therefore, the null hypotheses of no cointegration are rejected for the six models. The test is based on the selected lags of 6 for Models 1 and 2 and lags of 7 for Models 3 for CS1 and CS2, respectively.

Table 3: ARDL Bounds Test for Cointegration

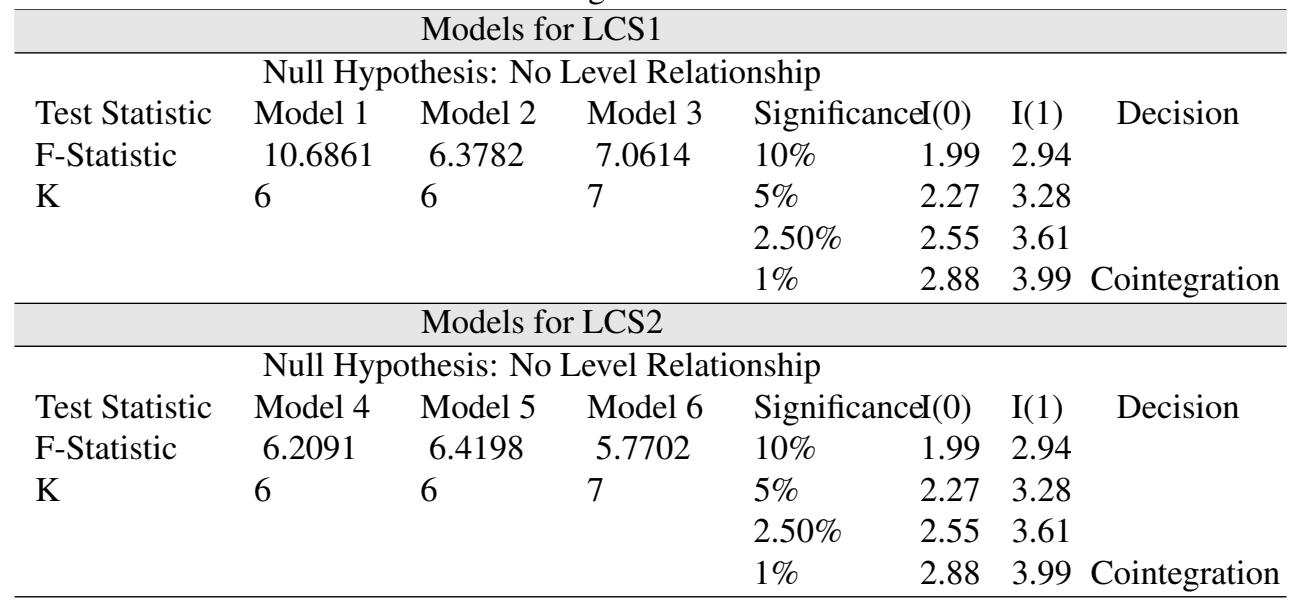

\subsection{Estimated Long-run Regression Results}

The estimates for the long-run models for CS1 across the three model variants are presented in Table 4. It is evident from the results that domestic interest rate and exchange rate expectation are statistically significant across the three models while the general price level proxied by CPI is significant for Models 1 and 2, as level of economic activities (RGDP) is significant in the case of Models 2 and 3 and real exchange rate volatility (RERV) is significant for Models 1 and 3. The direction of relationships however varies across the models. While CPI is directly related to CS1 in Model 1, it established an inverse relationship to the same variable in Model 2. The signs of RGDP are positive in both cases where it is statistically significant indicating that the episode of currency substitution (CS1) rises as the level of economic activities grow. In other words, the level of economic activity fuels currency substitution. 
Across the model variants, we found a positive relationship between domestic interest rate and the level of currency substitution. In other words, an increase in domestic interest tends to aggravate the incidence of currency substitution. As the cost of funds increases, investors resort to stockpiling foreign currency in anticipation of enjoying the premium in the near future. Conversely, foreign interest rate recorded inverse relationship with CS1 in both models that the variable is significant. Importantly, increased real exchange rate volatility increases the level of currency substitution narrowly defined, CS1. Of the three model variants, Model 1 is preferred as it has the lowest Bayesian information criterion (BIC) value (Table 4).

Table 4: Estimated Long-Run Coefficients for LCS1 Models

\begin{tabular}{lllllll}
\hline & \multicolumn{2}{c}{ Model 1 } & \multicolumn{2}{c}{ Model 2 } & \multicolumn{2}{c}{ Model 3 } \\
Variable & Coefficient & P-value & Coefficient & P-value & Coefficient & P-value \\
\hline C & 16.372 & 0.035 & -59.340 & 0.000 & -49.866 & 0.000 \\
LCPI & 1.870 & 0.000 & -1.270 & 0.085 & -1.050 & 0.135 \\
LRGDP & -0.847 & 0.352 & 8.190 & 0.000 & 7.633 & 0.000 \\
PLR_NGN & 0.090 & 0.000 & 0.068 & 0.000 & 0.067 & 0.001 \\
PLR_USA & -0.043 & 0.034 & -0.016 & 0.468 & -0.037 & 0.093 \\
LREREXP & -1.539 & 0.000 & 0.284 & 0.001 & 0.268 & 0.002 \\
LRERV & 1.917 & 0.000 & - & - & 0.997 & 0.007 \\
LNERV & - & - & 0.007 & 0.771 & 0.008 & 0.708 \\
D1 & 2.413 & 0.000 & 0.196 & 0.079 & - & - \\
D2 & - & - & - & - & 0.272 & 0.027 \\
R-squared & 0.976 & - & 0.971 & - & 0.971 & - \\
Adjusted R2 & 0.971 & - & 0.965 & - & 0.965 & - \\
BIC & -0.372 & - & -0.140 & - & -0.140 & - \\
DW- & 2.021 & - & 1.885 & - & 1.885 & - \\
statistics & & & & & & \\
F-statistics & 204.260 & 0.000 & 156.638 & 0.000 & 156.638 & 0.000 \\
\hline
\end{tabular}

Interestingly, the results for the broad definition of currency substitution, CS2, are related to characters attained for CS1 across three model variants. For example, like CS1, the coefficients of CPI for the CS2 model are all statistically significant. The same applies to the coefficients of RGDP which all yield positive signs and statistically significant. More so, the domestic interest rate all recorded positive coefficients and are statistically significant except in Model 5 (Table 5). However, foreign interest rate is only marginally significant in Model 5. Again, the coefficients of the real exchange rate volatility in Model 4 and 6 are positive and statistically significant, implying that exchange rate volatility promotes currency substitution in the country. Finally, the uncertainties associated with the entrenchment of democratic governance in 1999 as well as the rebasing of the country's GDP in 2010 are contributory factors to the rate of currency substitution. 
Currency Substitution and Exchange Rate Volatility in Nigeria:

An Autoregressive Distributed Lag Approach.

Ajibola et al.

Table 5: Estimated Long-Run Coefficients for LCS2 Models

\begin{tabular}{|c|c|c|c|c|c|c|}
\hline \multirow[b]{2}{*}{ Variable } & \multicolumn{2}{|c|}{ Model 4} & \multicolumn{2}{|c|}{ Model 5} & \multicolumn{2}{|c|}{ Model 6} \\
\hline & Coefficient & $\mathrm{P}$-value & Coefficient & P-value & Coefficient & $\mathrm{P}$-value \\
\hline $\mathrm{C}$ & -52.7764 & 0.0000 & -60.0509 & 0.0000 & -52.2340 & 0.0000 \\
\hline LCPI & -1.3222 & 0.0461 & -1.5703 & 0.0190 & -1.2702 & 0.0601 \\
\hline LRGDP & 7.8361 & 0.0000 & 8.2064 & 0.0000 & 7.7495 & 0.0000 \\
\hline PLR_NGN & 0.0541 & 0.0023 & 0.0189 & 0.2456 & 0.0538 & 0.0026 \\
\hline PLR_USA & -0.0205 & 0.3046 & -0.0336 & 0.0540 & -0.0206 & 0.3044 \\
\hline LREREXP & 0.3435 & 0.0001 & 0.5932 & 0.0000 & 0.3425 & 0.0001 \\
\hline LRERV & 0.8352 & 0.0292 & - & - & 0.8465 & 0.0286 \\
\hline LNERV & - & - & 0.0098 & 0.6649 & 0.0099 & 0.6374 \\
\hline D1 & 0.4194 & 0.0002 & - & - & 0.4145 & 0.0003 \\
\hline D2 & - & - & 0.0868 & 0.3639 & - & - \\
\hline R-squared & 0.975 & - & 0.973 & - & 0.975 & - \\
\hline $\begin{array}{l}\text { Adjusted } \\
\text { R2 }\end{array}$ & 0.969 & - & 0.966 & - & 0.968 & - \\
\hline $\mathrm{BIC}$ & -0.238 & - & -0.081 & - & -0.191 & - \\
\hline $\begin{array}{l}\text { DW- } \\
\text { statistics }\end{array}$ & 1.801 & - & 1.872 & - & 1.816 & - \\
\hline F-statistics & 165.395 & 0.000 & 135.650 & 0.000 & 154.562 & 0.000 \\
\hline
\end{tabular}

\subsection{Error Correction Model Results}

The ARDL short-run error correction results associated with the above long-run models for both measures of currency substitution are presented in tables 6 and 7. The selected ARDL specifications for Models 1 - 6 are $(1,0,0,2,1,4,0) ;(4,1,3,0,1,0,0) ;(1,0,3,0,1,0,2$, $0)$ and $(4,0,3,0,1,0,2) ;(4,0,3,0,1,4,0) ;(4,0,3,0,1,0,2,0)$, respectively. The Durbin Watson Statistics (DW) showed no indication of serial correlation in the models and the error correction terms for the model variants are negative and highly significant at $1 \%$ levels given further support to the existence of strong long-run correlation between the variables in the CS1 and CS2 models. The speed of adjustment for model variants ranged between 66 per cent and 79 per cent (see Tables 6 and 7).

Out of the three model variants estimated for the narrow definition of currency substitution, CS1, Model 1 yields the highest R-squared and the lowest BIC and is thus our preferred model (Table 6). Results under Model 1 indicated that inflation is a positive and statistically significant determinant of currency substitution in the country. In other words, an increase in inflation causes economic agents to keep their cash portfolio in US dollars. A decrease in domestic interest rate analogous to an expansionary monetary policy increases the level of currency substitution in the short run. On the other hand, an increase in foreign interest rate 
leads to an increase in currency substitution as such contractionary monetary policy measures in developed countries are associated with capital reversals and its attendant negative consequences in emerging economies such as Nigeria (Table 6).

As earlier established under the long run regression, increased real exchange rate volatility aggravates the problem of currency substitution as agents tend to increase their holdings of foreign currency as a way of risk hedging (Table 6). The dummy variables used in the models are also positive, statistically and highly relevant indicating that the events of that period contributed to the increase of dollarization in the economy in the short run.

Table 6: Estimated Short-Run Coefficients LCS1 Models

\begin{tabular}{lllllll}
\hline & \multicolumn{2}{c}{ Model 1 } & \multicolumn{2}{c}{ Model 2 } & \multicolumn{2}{c}{ Model 3 } \\
Variable & Coefficient & P-Value & Coefficient & P-Value & Coefficient & P-Value \\
\hline$\Delta$ LCS1(-1) & - & - & -0.032 & 0.758 & 0.000 & 0.000 \\
$\Delta$ LCS1(-2) & - & - & 0.121 & 0.190 & 0.000 & 0.000 \\
$\Delta$ LCS1(-3) & - & - & 0.286 & 0.001 & 0.000 & 0.000 \\
$\Delta$ LCPI & 1.801 & 0.045 & 0.849 & 0.442 & -0.408 & 0.723 \\
$\Delta$ LRGDP & -0.642 & 0.123 & 0.671 & 0.312 & 1.074 & 0.093 \\
$\Delta$ LRGDP(-1) & - & - & -3.556 & 0.000 & -3.250 & 0.000 \\
$\Delta$ LRGDP(-2)) & - & - & -2.663 & 0.000 & -1.646 & 0.005 \\
$\Delta$ PLR_NGN & 0.029 & 0.181 & 0.043 & 0.060 & 0.048 & 0.087 \\
$\Delta$ PLR_NGN(-1) & -0.058 & 0.016 & - & - & - & - \\
$\Delta$ PLR_USA & 0.124 & 0.004 & 0.145 & 0.002 & 0.135 & 0.004 \\
$\Delta$ LREREXP & 0.115 & 0.286 & 0.178 & 0.164 & 0.234 & 0.060 \\
$\Delta$ LREREXP(-1) & 1.061 & 0.000 & - & - & - & - \\
$\Delta$ LREREXP(-2) & 0.887 & 0.009 & - & - & - & - \\
$\Delta$ LREREXP(-3) & 0.484 & 0.004 & - & - & - & - \\
$\Delta$ LRERV & -1.116 & 0.099 & - & - & -0.559 & 0.023 \\
$\Delta$ LRERV(-1) & 0.000 & 0.000 & - & - & 1.110 & 0.000 \\
$\Delta$ LNERV & 0.000 & 0.000 & -0.007 & 0.585 & 0.000 & 0.974 \\
D1 & - & - & 0.326 & 0.065 & 0.000 & 0.000 \\
D2 & - & - & - & - & 0.233 & 0.240 \\
ECM(-1) & -0.666 & 0.000 & -0.751 & 0.000 & -0.776 & 0.000 \\
R-squared & 0.976 & - & 0.971 & - & 0.971 & - \\
Adjusted R2 & 0.971 & - & 0.965 & - & 0.965 & - \\
BIC & -0.372 & - & -0.140 & - & -0.140 & - \\
DW-statistics & 2.021 & - & 1.885 & - & 1.885 & - \\
F-statistics & 204.260 & 0.000 & 156.638 & 0.000 & 156.638 & 0.000 \\
\hline
\end{tabular}

In the case of the broad definition of currency substitution, CS2, Model 4 is our preferred model since it yielded the lowest BIC value of -0.2376 (Table 7). According to the model results, a decreased level of GDP generates a higher level of currency substitution (CS2), albeit with one to two periods lags. This is like the findings under Model 1. However, an increase in 
Currency Substitution and Exchange Rate Volatility in Nigeria:

An Autoregressive Distributed Lag Approach.

Ajibola et al.

domestic interest rate generates higher currency substitution, contrary to the outcomes generated under Model 1. As established under the model fitted to LCS1, an increase in foreign interest rate leads to an increase in currency substitution and this finding is consistent across Models 3 and 4 (Table 7). Also, results under Model 4 showed that expected changes in the real exchange rate increases the incidence of currency substitution. This is consistent with the findings under Model 1. With regards to real exchange rate volatility, Model 4 indicates that it leads to higher currency substitution albeit with a lag of one period. In other words, an increase in the current level of real exchange rate volatility leads to higher incidence of currency substitution in the next quarter (Table 7).

Table 7: Estimated Short-Run Coefficients for LCS2 Models

\begin{tabular}{lllllll}
\hline & \multicolumn{2}{c}{ Model 4 } & \multicolumn{2}{c}{ Model 5 } & \multicolumn{2}{c}{ Model 6 } \\
\multicolumn{1}{c}{ Variable } & Coefficient & P-Value & Coefficient & P-Value & Coefficient & P-Value \\
\hline$\Delta$ LCS2(-1) & -0.023 & -0.820 & 0.061 & -0.581 & -0.023 & -0.822 \\
$\Delta$ LCS2(-2) & 0.036 & -0.675 & 0.189 & -0.056 & 0.038 & -0.659 \\
$\Delta$ LCS2(-3) & 0.225 & -0.009 & 0.282 & -0.003 & 0.236 & -0.007 \\
$\Delta$ LCPI & -0.640 & -0.562 & -0.620 & -0.586 & -0.542 & -0.624 \\
$\Delta$ LRGDP & 1.054 & -0.094 & 1.126 & -0.094 & 0.968 & -0.129 \\
$\Delta$ LRGDP(-1) & -3.068 & 0.000 & -3.558 & 0.000 & -3.064 & 0.000 \\
$\Delta$ LRGDP(-2) & -2.085 & 0.000 & -2.121 & -0.002 & -2.118 & -0.001 \\
$\Delta$ PLR_NGN & 0.048 & -0.029 & 0.026 & -0.293 & 0.049 & -0.029 \\
$\Delta$ PLR_USA & 0.080 & -0.059 & 0.122 & -0.008 & 0.081 & -0.057 \\
$\Delta$ LREREXP & 0.244 & -0.046 & 0.174 & -0.166 & 0.240 & -0.050 \\
$\Delta$ LREREXP(-1) & - & - & -0.352 & -0.009 & - & - \\
$\Delta$ LREREXP(-2) & - & - & -0.054 & -0.691 & - & - \\
$\Delta$ LREREXP(-3) & - & - & -0.447 & -0.001 & - & - \\
$\Delta$ LRERV & -0.316 & -0.207 & - & & -0.301 & -0.233 \\
$\Delta$ LRERV(-1) & 1.080 & 0.000 & - & & 1.070 & 0.000 \\
$\Delta$ LNERV & - & & 0.000 & -0.994 & -0.003 & -0.790 \\
D1 & 0.438 & -0.009 & - & & 0.440 & -0.009 \\
D2 & - & & 0.023 & -0.887 & - & - \\
ECM(-1) & -0.766 & 0.000 & -0.792 & 0.000 & -0.769 & 0.000 \\
R-squared & 0.975 & - & 0.973 & - & 0.975 & - \\
Adjusted R2 & 0.969 & - & 0.966 & - & 0.968 & - \\
BIC & -0.238 & - & -0.081 & - & -0.191 & - \\
DW-statistics & 1.801 & - & 1.872 & - & 1.816 & - \\
F-statistics & 165.395 & 0.000 & 135.650 & 0.000 & 154.562 & 0.000 \\
\hline
\end{tabular}




\subsection{Diagnostics Tests}

The results for the Breusch-Godfrey Serial Correlation LM Test and the Breush-PaganGodfrey heteroscedasticity tests are presented in Table 8.

The test results indicate the absence of serial correlation in the residuals of the six estimated models. Also, Breush-Pagan-Godfrey heteroscedasticity tests revealed that the null of homoscedasticity could not be rejected, indicating six estimated models are homoscedasticconsistent.

Table 8: Diagnostic Tests

\begin{tabular}{|c|c|c|c|}
\hline \multicolumn{4}{|l|}{ CS1 Model 1} \\
\hline \multicolumn{4}{|c|}{ Breusch-Godfrey Serial Correlation LM Test } \\
\hline F-statistic & 0.0464 & Prob. $F(2,73)$ & 0.9547 \\
\hline Obs*R-squared & 0.1155 & Prob. Chi-Square(2) & 0.9439 \\
\hline \multicolumn{4}{|c|}{ Heteroskedasticity Test: Breusch-Pagan-Godfrey } \\
\hline F-statistic & 0.5278 & Prob. $F(1,88)$ & 0.4695 \\
\hline Obs*R-squared & 0.5365 & Prob. Chi-Square(1) & 0.4639 \\
\hline \multicolumn{4}{|l|}{ CS1 Model 2} \\
\hline \multicolumn{4}{|c|}{ Breusch-Godfrey Serial Correlation LM Test } \\
\hline F-statistic & 1.6310 & Prob. $F(2,72)$ & 0.2029 \\
\hline Obs*R-squared & 3.944103 & Prob. Chi-Square(2) & 0.1392 \\
\hline \multicolumn{4}{|c|}{ Heteroskedasticity Test: Breusch-Pagan-Godfrey } \\
\hline F-statistic & 0.17931 & Prob. $F(1,88)$ & 0.6730 \\
\hline Obs*R-squared & 0.183012 & Prob. Chi-Square(1) & 0.6688 \\
\hline \multicolumn{4}{|l|}{ CS1 Model 3} \\
\hline \multicolumn{4}{|c|}{ Breusch-Godfrey Serial Correlation LM Test } \\
\hline F-statistic & 0.2035 & Prob. $F(2,74)$ & 0.8163 \\
\hline Obs*R-squared & 0.5032 & Prob. Chi-Square(2) & 0.7776 \\
\hline \multicolumn{4}{|c|}{ Heteroskedasticity Test: Breusch-Pagan-Godfrey } \\
\hline F-statistic & 0.0308 & Prob. $F(1,89)$ & 0.8611 \\
\hline Obs*R-squared & 0.0315 & Prob. Chi-Square(1) & 0.8591 \\
\hline \multicolumn{4}{|l|}{ CS2 Model 4} \\
\hline \multicolumn{4}{|c|}{ Breusch-Godfrey Serial Correlation LM Test } \\
\hline F-statistic & 0.8028 & Prob. F(2,71) & 0.4521 \\
\hline Obs*R-squared & 2.0124 & Prob. Chi-Square(2) & 0.3656 \\
\hline \multicolumn{4}{|c|}{ Heteroskedasticity Test: Breusch-Pagan-Godfrey } \\
\hline F-statistic & 0.0795 & Prob. F(1,88) & 0.7787 \\
\hline Obs*R-squared & 0.0812 & Prob. Chi-Square(1) & 0.7757 \\
\hline
\end{tabular}


Currency Substitution and Exchange Rate Volatility in Nigeria:

An Autoregressive Distributed Lag Approach.

Ajibola et al.

Table 8 contd.: Diagnostic Tests

\begin{tabular}{|c|c|c|c|}
\hline \multicolumn{4}{|l|}{ CS2 Model 5} \\
\hline \multicolumn{4}{|c|}{ Breusch-Godfrey Serial Correlation LM Test } \\
\hline F-statistic & 0.97553 & Prob. F(2,69) & 0.3821 \\
\hline Obs*R-squared & 2.50239 & Prob. Chi-Square(2) & 0.2862 \\
\hline \multicolumn{4}{|c|}{ Heteroskedasticity Test: Breusch-Pagan-Godfrey } \\
\hline F-statistic & 0.0045 & Prob. F $(1,88)$ & 0.9465 \\
\hline Obs*R-squared & 0.0046 & Prob. Chi-Square(1) & 0.9458 \\
\hline \multicolumn{4}{|l|}{ CS2 Model 6} \\
\hline \multicolumn{4}{|c|}{ Breusch-Godfrey Serial Correlation LM Test } \\
\hline F-statistic & 0.6608 & Prob. $F(2,70)$ & 0.5196 \\
\hline Obs*R-squared & 1.6863 & Prob. Chi-Square(2) & 0.4304 \\
\hline \multicolumn{4}{|c|}{ Heteroskedasticity Test: Breusch-Pagan-Godfrey } \\
\hline F-statistic & 0.1020 & Prob. F(1,88) & 0.7502 \\
\hline Obs*R-squared & 0.1042 & Prob. Chi-Square(1) & 0.7469 \\
\hline
\end{tabular}

\subsection{Conclusion and Policy Recommendations}

This study employed the autoregressive distributed lag (ARDL) technique to examine the relationship between exchange rate volatility and currency substitution in Nigeria using quarterly data. Two measures of currency substitution were employed, and the study modified the model by incorporating structural breaks. Empirical evidence supports a positive relationship between real exchange rate volatility and currency substitution as risk averse agents tend to increase their holdings of foreign currency as a way of hedging against exchange rate risks. These findings are consistent with Yunusa and Akinlo (2008), Doguwa (2014) and Bawa et al. (2015).

As highlighted in the stylized fact, the study also found an increase in the degree of currency substitution in the country as indicated in the trend of the two measures of currency substitution, reaching its peak in the first quarter of 2014. However, the broad measure CS2 remained largely within the $\mathrm{IMF}^{6}$ threshold of 30 per cent for most of the period under review. This was further collaborated by the positive relationship between currency substitution and output (RGDP) in the long run model indicating that currency substitution is likely to increase as the level of economic activities grows.

The key policy implication of currency substitution is that it reduces monetary policy effectiveness consequently, resulting in loss of monetary policy independence. Based on our

\footnotetext{
${ }^{6}$ Monetary Policy in Dollarized Economies, IMF Occasional Paper No. 171, 1999
} 
model results, the paper therefore, recommends that the Central Bank of Nigeria should continue to vigorously pursue its core mandate of ensuring monetary and price stability in order to stem the spate of currency substitution in the country. The CBN needs to continuously undertake and sustain the necessary economic reforms needed to deepen the financial market as well as strengthen the Naira. Efforts to further diversify the economy should be of paramount interest to boost the base for foreign exchange earnings. This will discourage agents from switching their cash portfolio to foreign currencies.

\section{References}

Adeniji, S. (2013). Investigating the relationship between currency substitution, exchange rate and inflation in Nigeria: An Autoregressive Distributed Lag (ARDL) Approach. MPRA Paper, 52551.

Agenor, P. R., \& Khan, M. S. (1992). Foreign currency deposits and the demand for money in developing countries. IMF Working Paper, WP/92/1, Washington D.C

Agenor, P. R. (2004). The economics of adjustment and growth, Harvard University Press, Second Edition.

Akinlo, A. E. (2003). Exchange rate depreciation and currency substitution in Nigeria. African Review of Money Finance and Banking, 139- 143.

Arize, A. C. (1991). Currency substitution in Korea. The American Economist, 35(2), 67 72.

Bahmani-Oskooee, M., \& Ilker, D. (2003). On the link between dollarization and inflation: Evidence from Turkey. Comparative Economic Studies, 45, 306-328.

Batten, Dallas, S., \& Hafer, R. W. (1984). Currency substitution: A test of its importance. Federal Reserve Bank of St. Louis Review, August/September 5-12.

Baumol, W. J. (1952). The transactions demand for cash: An inventory theoretic approach. Quarterly. Journal of economics, 66, 545-556

Bawa, S., Omotosho, B. S., \& Doguwa, S. I. (2015). Ratchet effects in currency substitution: An Application to Nigeria. CBN Journal of Applied Statistics, 5, 1-23

Boamah, D., Guy, K., Grosvenor, T., \& Lescott, A. (2012). Currency substitution: Evidence from the Caribbean. Journal of Business, Finance and Economics in Emerging Economies, 7(1), 1-20.

Calvo, G. A., \& Vegh, C. A. (1992). Currency Substitution in Developing Countries: An Introduction. IMF Working Paper, 92-40. 
Currency Substitution and Exchange Rate Volatility in Nigeria:

An Autoregressive Distributed Lag Approach.

Ajibola et al.

Chang, R. (2000). Dollarization: A score card. Federal Reserve Bank of Atlanta Economic Review, Third Quarter, 85(3), 1-11.

Clements, B. J., \& Schwartz, G. (1992). Currency substitution: The recent experience in Bolivia. IMF Working Papers 92-65.

Clower, R. W. (1967). A Reconsideration of the micro-fundamentals of Monetary Theory. Western Economic Journal, 6, 1-19.

Cuddington, J. T. (1983). Currency substitution, capital mobility and money demand. Journal of international money and finance, 2, 111-333.

Cuddington, J. T. (1989). Review of currency substitution: Theory and evidence from Latin America. J. money credit bank, 21, 267-271.

Dallas, B. S., \& Hafer, R. W. (1984). Currency substitution: A test of its importance. Federal Reserve Bank of St. Louis Review, 5-12.

De Nicolo, G., Honohan, P., \& Ize, A. (2003). Dollarization of the banking system: Good or Bad. World Bank Policy Research Working Paper. 3116, 18-35.

De Nicolo, G., Honohan, P. \& Ize, A. (2005). Dollarization of the Banking System: Causes and Consequences. Journal of Banking and Finance 29, 1697-1727.

Doguwa, S. I., Olowofeso, O. E., Uyaebo, S. O., Adamu, I., \& Bada, A. S. (2014). Structural breaks, cointegration and demand for money in Nigeria. CBN Journal of Applied Statistics, 5(1), 1-19.

Doguwa, S. I. (2015). Currency substitution: Evidence from Nigeria. CBN Journal of Applied Statistics, 5(2), 1-23.

Elkhafif, M. A. T. (2002). Exchange rate policy and currency substitution: The case of Africa's emerging economies. African Development Bank Economic Research Papers, No. 71 .

Girton, L., \& Roper, D. (1976). Theory and implications of currency substitution. International financial discussion papers, Federal Reserve Board.

Girton, L., \& Roper, D. (1981). Theory and implications of currency substitution. Journal of Money, Credit and Banking, 13(1), 12-30.

Hisao, K., \& Masao, K. (2014). Does currency substitution affect exchange rate volatility? International Journal of Economics and Financial Issues, 4(4), 698-704.

Ho, N. H. (2003). Currency Substitution and the Case of Macao. Monetary Authority of Macau, 25-38. 
Huseyin, K., Abdurrahman, I., \& Gylych, J. (2015). Currency substitution: evidence from Nigeria. The Empirical Economics Letters, 14(7), 737-744.

IMF (1999). Monetary Policy in Dollarized Economies, IMF Occasional Paper No. 171.

Laopodis, N. T. (2011). Currency substitution and European Monetary Union. Journal of Applied Business Research, 14(4), 47-52.

Lionel, E., \& Ubi P. S. (2010). The currency substitution phenomenon: Is the Nigerian economy immune? Journal of Economics Theory, 4(1), 9-13.

Lucas, R. \& Stoky, N. L. (1987). Money and Interest in a Cash-in-Advance Economy. Econometrica, 55, 491-513.

Mckinnon, R. I. (1982). Currency substitution and Instability in the world dollar standard. American economic review, 72(3), 320-333.

Miles, M. (1978). Currency substitution, flexible exchange rates, and monetary independence. The American Economic Review, 68(3), 428-436.

Mizen, P. D. \& Pentecost, E. J. (1996). Currency Substitution in Theory and Practice, in Mizzen, P. and J. Pentecost, (eds). The Macroeconomics of International Currencies: Theory, Policy and Evidence. Edward Elgar Publishing Company, USA.

Mostafa, S., Mohammad, H. M., Ahmad, S., \& Sara, S. (2016). Currency Substitution Theory, a New Chanel to Enter the Exchange Rate as the Monetary Transmission Mechanism. Atlantic Review of Economics - 2nd Volume - 2016, 6 - 7.

Pesaran, M. H., \& Shin, Y. (1999). An autoregressive distributed lag modeling approach to cointegration analysis. Centennial Volume of Ragnar Frisch, eds. S. Strom, A. Holly and P. Diamond, Cambridge University Press.

Pesaran, M. H., Shin, Y., \& Smith, R. (2001). Bound testing approaches to the analysis of level relationships. Journal of Applied Econometrics, 16(3), 289 - 326.

Phillips, P. C. B., \& Perron, P. (1988). Testing for unit root in time series regression. Biometrika, 75(2), 335 - 46.

Schuler, K. (2002). The Basics of Dollarization. Joint Economic Committee Staff Report, Office of the Chairman, Connie Mack.

Tanzi, V., \& Blejer, M. I. (1982). Inflation, interest rate and currency substitution in developing economies: A discussion of some major issues. World Development 10, 781 789.

Thomas, L. R. (1985). Portfolio theory and currency substitution. Journal of money, credit and banking, 17(3), 347-357. 
Currency Substitution and Exchange Rate Volatility in Nigeria:

An Autoregressive Distributed Lag Approach.

Ajibola et al.

Tobin, J. (1969). A general equilibrium approach to monetary theory. Journal of money, credit and banking, 1(1), 15-29.

Tobin, J. (1956). The Interest rate elasticity of Transactions demand for cash: Review of Economics and Statistics, 38, 241-247.

Udoh, A. P., \& Udeaja, E. A. (2019). Asymmetric effects of financial dollarization on nominal exchange rate volatility in Nigeria. The Journal of Economic Asymmetries, 19(C).

Yeyati, E. L. (2004). Financial dollarization: Evaluating the consequences. Econometric Society Latin American Meetings.

Yeyati, E. L. (2006). Financial Dollarization: Evaluating the consequences. Economic policy, 21(45), 61-118.

Yinusa, D. O., \& Akinlo, A. E. (2008). Exchange rate volatility and the extent of currency substitution in Nigeria. Indian Economic Review, 43(2), 161-181. 